\title{
A Concentration Analysis in the Turkish Domestic Air Transportation Industry using with CRm and Herfindahl-Hirschman Indexes
}

\author{
Türkiye İç Hat Hava Taşımacılığı Üzerine Herfindahl-Hirshman Endeksi \\ ve CRm Yoğunlaşma Oranı Analizi ile Piyasa Yoğunlaşmasının Tespit \\ Edilmesi
}

\author{
Kasım KİRACI** \\ Mehmet YAŞAR* \\ Selçuk KAYHAN ${ }^{* * *}$ \\ Temel Caner USTAÖMER ${ }^{* * * * *}$
}

\begin{abstract}
Concentration means that economic activities are dominated or owned by a small number of firms in any market. Accordingly, there is a negative relationship between concentration ratio in the market and level of competition. In other words, as the concentration rate increases, level of competition decreases and vice-versa. The low market concentration ratio and imperfect competition are common occurences in the emerging countries such as Turkey. In this study, concentration ratio and level of competition of the top five airports in Turkey will be examined by years. In this context, the airlines' (using these top five airports) number of passengers and cargo volumes between 2012 and 2015 will be used to analyse. This study is significant as it is the first study to investigate airport market concentration and market structure in Turkey. In this context, the relationship between domestic air transportation concentration ratio and market structure will be demonstrated with using M-Firm Concentration Ratio (CRm) and Herfindahl-Hirschman Index (HHI) analysis methods. After the analyses, our results justified that market structure is far from competition. In addition, there are recommendations and determinations to what to do for ensuring competition and maintaining it truly in this study.
\end{abstract}

Keywords: Herfindahl-Hirshman Index, M-Firm Concentration Ratio, Airline Companies, Competition, Market Structure

$\ddot{O} \mathbf{z}$

Yoğunlaşma, herhangi bir piyasada ekonomik faaliyetlerin az sayıda firmanın domine edilmesi ya da sahiplenilmesi anlamında kullanılmaktadır. Buna göre piyasadaki yoğunlaşma oranı ile rekabet düzeyi arasında negatif yönlü bir ilişki söz konusudur. Diğer bir ifade ile piyasadaki yoğunlaşma oranı artıkça rekabet düzeyi azalır, yoğunlaşma oranı azaldıkça rekabet düzeyi artar. Türkiye gibi gelişmekte olan ülke piyasalarında piyasa yoğunlaşma oranın düşük olması ve eksik rekabet sık rastlanılan bir durumdur. Bu çalışma kapsamında Türkiye'deki faaliyet gösteren en büyük beş havalimanının piyasadaki yoğunlaşma oranı ve rekabet düzeyi incelenecektir. Bu kapsamda söz konusu havaalanlarını kullanan havayolu işletmelerinin 2012-2015 yılları arasında bu havaalanlarındaki yolcu sayıları ve kargo miktarları incelenecektir. Bu çalışma Tükiye'deki havalimanlarında pazar yoğunlaşması ve piyasa yapısını inceleyen ilk araştırma olması nedeniyle önemlidir. Türkiye'de havacılık piyasasında yoğunlaşma ve piyasa yapısı arasındaki ilişki M - Firma Yoğunlaşma Oranı ve Herfindahl-Hirschman Endeksi Analiz yöntemleri kullanılarak iç hat hava taşımacılığındaki piyasa yapısının durumu ortaya konmaya çalışılacaktır. Yapılan analizler sonucunda piyasanın rekabetçi yapıdan uzak olduğu ortaya çıkarılmıştır. Buna ek olarak çalışmada rekabetin sağlanması ve sağlıklı bir şekilde işlemesine yönelik yapılması gerekenlerle ilgili tespit ve öneriler yer alacaktır.

\footnotetext{
** Research Assistant, School of Civil Aviation, İskenderun Teknik Üniversitesi, kasim.kiraci@iste.edu.tr

* Research Assistant, Anadolu University, Department of Civil Aviation Management, mehmet_yasar@anadolu.edu.tr

*** Lecturer, Dept. of Civil Aviation Management, Amasya University, selcuk.kayhan@amasya.edu.tr

**** Research Assistant, Dept. of Civil Aviation Management, Anadolu University, temelcanerustaomer@anadolu.edu.tr
}

Kirac1, K , Yaşar, M, Kayhan, S , Ustaömer, T . (2017). A Concentration Analysis In The Turkish Domestic Air Transporation Industry using with $\mathrm{CRm}$ and Herfindahl-Hirschman Indexes. Gaziantep University Journal of Social Sciences, 16 (3), 687-704. DOI: 10.21547/jss.287910 
Anahtar Kelimeler: Herfindahl-Hirshman Endeksi, M-Firma Yoğunlaşma Oranı, Havayolu İşletmeleri, Rekabet, Piyasa Yapıları

\section{Introduction}

Competition is defined as sharing limited sources for unlimited needs of people (Aktan \& Y.Vural, 2004). Therefore, in the classic economy, competition is behaviour of companies for reducing prices to fight back excessive supply (McNulty, 1968).

While classic economists define competition as market process, Neo-Classic economists define it as market structure and then pure competition fact is at the top of agenda. According to Classic economists, output of process is two companies which turn against each others. However, Neo-Classic economists state that there are many sellers and buyers, flow of information is complete and there is no entry or exit barriers in the pure competition. Moreover, market is homogen and share of market can be divided (Özkan, 2007).

If all conditions which Neo Classic thought are provided, pure competition can be realized. Pure competition is not possible in the real world (Aktan \& Y.Vural, 2004). If all conditions mentioned above are not realised, markets are defined as imperfect competition. These markets; monopol, duopol and oligopol. Table 1 shows features of these markets (Grant, 2008).

Table 1: Market Structures

\begin{tabular}{lcccc}
\hline & Perfect Competition & Oligopol & Duopol & Monopol \\
\hline Concentration & Many companies & A few companies & Two & One company \\
Entry and Exit Barriers & No barrier & Significant entry barriers & High entry barriers \\
Product Diversification & Homogen & Potential for product diversification \\
Accessibility to & Product/Service & & \\
Information & No barrier to flow of & Access to information is limited
\end{tabular}

Source: Robert M.Grant, Contemporary Strategy Analysis (UK: Backwell Publishing, Sixth Edition. 2008)

Imperfect competition can be observed in developed countries, such as Turkey. In imperfect markets, thera are entry and exit barriers, players in the market can differentiate their products and access to informatin is limited wholly or partially (Silva, 2007; Batmaz \& Özcan, 2008).

Concentration determines market structure and is related to the number of buyers and sellers in the market and size distribution (Süslü \& Baydur, 1999). Market concentration is related to the situation that limited number of companies have economic resources and activities. In imperfect markets, market concentration is common (Durukan \& Hamurcu, 2009).

To measure market power, concentration indexes which provides helpful and practical indicators are utilised. These indexes give important information about market concentration and competition level (Pehlivanoğlu \& Tekçe, 2013). For this purpose, as part of StructureConduct-Performance (SCP) approach, Herfindhal-Hirschman Index and M-firm Concentration Ratio analyses are widely utilised (Polat, 2007; Pehlivanoğlu and Tekçe, 2013).

For this research, as part of application area, Turkish aviation domestic market was chosen. There are two main reasons for choosing this application area. Firstly, we did not find 
any research related to this topic in Turkey. Secondly, after 2003, domestic deregulation was a milestone for Turkish Civil Aviation (Battal, Yılmaz, \& Ateş, 2006) and to reveal the effect of increased competition on domestic markets (Gerede \& Orhan, 2015).

In this context, the following research questions are answered:

- What is the level of market structure in Turkish domestic air transport?

- What is the level of market structure in Turkish domestic air cargo transport?

In the first part of this research, general structure of Turkey's aviation industry will be mentioned. All data in this research was obtained from General Directorate of State Airports Operations statistical annuals. Second part deals with the relationship between concentration and market structurer. The last part, in accordance with M-Firm concentration ratio and Herfindhal-Hirschmann index, examines Turkish domestic passenger and cargo transport and reveal market structures.

\section{Turkey's Air Transport Industry}

Air transport industry generated 819,4 billion dollars in gross domestic product of 2013 in Turkey (TÜİK,2014). Direct effect of aviation industry is 5,8 billion dollars, indirect effect is 4,3 billion dollars and induced effect is 2,01 billion dollars (ATAG, 2014). The total effect of aviation industry is responsible for $1,5 \%$ of gross domestic product.

In 1978, the United States of America deregulated its domestic markets. After 5 years, in 1983, thanks to No.2920 of Civil Aviation Law, private airlines were given permission to carry out domestic operations in Turkey (Battal, Y1lmaz, \& Ateş, 2006; Oktal \& Gerede, 2002). Before this deregulation, only Turkish Airlines (the flag carrier) was flying in the domestic routes. After the deregulation, new airlines were established and the number of airlines increased. However, reasons such as technical inadequacy, lack of qualified employees and infrastructure problems led some airlines to go bankrupt and stop operations (Korul \& Küçükonal, 2003). Moreover, this law did not deregulate domestic markets completely. 9/11 attacks and economic crises (IATA, 2011) affected aviation industry in the whole world adversely (Battal, Yılmaz, \& Ateş, 2006). The government in Turkey modified No.2920 to reduce negative impacts and gave airlines the chance to determine their fares freely (TBMM, 2001). In 2003, deregulation has started in the domestic markets and private airlines started domestic operations (Battal, Yılmaz, \& Ateş, 2006; Gerede \& Orhan, 2015). All these developments expanded airline market and passenger numbers, cargo and commercial airplane traffic incresed significantly year by year. In the beginning of deregulation, passenger number stood at 9,1 millions. After only one year, passenger number reached to 85 millions (UBAK, 2014). In Turkey, the number of all airplanes in 2003 was only 162. In the December of 2015, this number reached to 489. In the same period, seat capacity incresed from 27.599 to 90.259 and cargo capacity grew from $302.737 \mathrm{~kg}$ to $1.759 .600 \mathrm{~kg}$ (ATIG, 2015; UBAK, 2014; SHGM, 2015).

\section{Summary of Statistical Data Related To Turkey's Air Transport}

In this part, to explain present situation of Turkey's air transport better, the data of General Directorate of State Airports Authority between 2012 and 2015 were scanned and taking account of commercial airplane, passenger and cargo traffic, top 10 airports were tabularised. Related tables can be found in annexes. Annex A gives the data related to commercial airplane traffic, Annex B shows passenger traffic data and cargo traffic data can be found in Annex C.

According to Appendix A, since end of 2015, commercial airplane traffic increased by $9,5 \%$ year-on-year. If we look at the increase for domestic and international routes seperately, 
percental increase shows parallelism with Turkey-wide. In terms of top 10 airports, Istanbul Ataturk Airport is responsible for $36 \%$ of total commercial traffic (IATA: IST, ICAO: LTBA ${ }^{1}$ ). IST/LTBA is followed by Istanbul Sabiha Gokcen, Antalya, Ankara Esenboga airports respectively.

Appendix B shows top 10 airports in terms of passenger traffic in 2012 and 2015. In the end of 2015, Turkey-wide passenger traffic reached to 165,7 millions and increased by $10,9 \%$ year-on-year. Domestic and international routes reveal differences in numbers. While increase in domestic routes was 12,2\%, international routes saw 9,6\% increase. Total increase in traffic reached to more than 16 millions. In terms of top 10 airports, Ataturk Airport accounts for 34\% of total traffic and this percentage is close to its commercial traffic percentage of $36 \%$. Istanbul Ataturk Airports is followed by Antalya, Istanbul Sabiha Gokcen and Ankara Esenboga Airports respectively.

Appendix C demonstrates transported cargo quantity between the years 2012 and 2015. In the end of 2015, cargo quantity increased by $15,6 \%$ year-on-year and this increased was derived from increase in international routes. Ataturk Airport is responsible for $86 \%$ of cargo traffic. By contrast with passenger and commercial airplane traffic, Antalya Airport was ranked at the 6.

\section{Market Level Competition}

"Competition'" is defined as a company that it is trying to succeed against by achieving goals of sale amount, profit and market share (Bas, 2005: 38). Polat (2007) defines market structure as a method that classifies markets according to competition. Market is classified as pure competition, monopol, monopolistic competition and oligopoly. Examining market structures at the present time reveals that monopolistic competition and oligopoly markets are more common, on the other hand, pure competition and monopol markets are rare (2007: 99).

Pehlivanoglu and Tekce (2013) define monopolistic competition and oligopoly markets in their study. In monopolistic competition, there are many companies in the market but their effects on price are not significant. On the other hand, in oligopoly markets, there are few companies but they have power to determine prices.

Concentration is defined as the degree to which the output in a market or an industry is accounted for by only a few firms. It differs according to market structure and competition level (Uysal and Ozturk, 2005: 274; Pehlivanoglu ve Tekce, 2013: 373). In other words, it is related to whether structure in the market is open to competition or not (Günlü, 2011: 102). Concentration analysis is utilised to measure competition between firms in a market and reveal unfair competition. The measurement of concentration level reveals market structure, market behaviour and market performance in a certain industry (Baş, 2005: 39).

There are many methods to measure concentration level in a market or an industry. Herfindahl-Hirschman and M-Firm concentration ratio are two of commonly used methods (Uysal and Ozturk, 2005: 275). The following part gives detailed information about mentioned concentration indexes.

\section{Herfindahl-Hirschman Index (HHI)}

This index is accepted as a good one because it takes account of firm numbers and their market shares (Kaynak and Ari, 2011: 48). Herfindahl-Hirschman Index is calculated by squaring the market share of each firm competing in a market and its formula is as follows (Uysal and Ozturk, 2005:276).

\footnotetext{
${ }^{1}$ IST: IATA's (International Air Transportation Association) three digits airport code; LTBA: ICAO's (International Civil Aviation Organization) four digits code
} 


$$
\begin{aligned}
& \left(S_{i}\right) \text { market shares of firms }(\%) \\
& H H I=\sum\left(S_{i}\right)^{2} \quad \mathrm{i}=1 \ldots \ldots n \quad \text { that is to say } \\
& H H I=s_{1}^{2}+s_{2}^{2}+s_{3}^{2}+s_{4}^{2} \ldots \ldots \ldots \ldots s_{n}^{2} \\
& \text { Example; } H H I=(15)^{2}+(15)^{2}+(15)^{2}+(15)^{2}(20)^{2}+(20)^{2} \\
& \qquad=225+225+225+225+400+400=1700
\end{aligned}
$$

While the highest $\mathrm{H}-\mathrm{H}$ index value for a market can be 10.000 if there are many firms in the market, $\mathrm{H}-\mathrm{H}$ index value can be near the zero. Generally, the value of $0-2.000 \mathrm{H}-\mathrm{H}$ index qualifies low concentration market, the value of 2.000-4.000 H-H index indicates medium concentration market and the value of 4.000-10.000 H-H index shows high concentration market. According to United States of America's "Merger Guideline", there is pure competition for HHI below 1000; there is monopolistic competition for HHI 1.000-1.800 and there is oligopoly competition for HHI above 1.800 (Polat, 2007, s. 100; Durukan \& Hamurcu, 2009, s. 78; Pehlivanoğlu \& Tekçe, 2013, s. 375).

\section{M-Firm Concentration Ratio $\left(C R_{M}\right)$}

This ratio is generally calculated for 4 or 8 firms. In the low concentration markets, competition level is high, in the high concentration markets, competition level is low. If concentration ratio reaches to $100 \%$, this means that one firm dominates the market. M - Firm Concentration Ratio (CRM) is calculated as follows (Polat, 2007:100);

$C R_{M}=\frac{1}{X} \sum_{i=1}^{m} X_{i}$

$C R_{M}$ : shows concentration ratio for " $\mathrm{M}$ " number of firms.

$X_{i}$ : shows the value of " $\mathrm{x}$ " variable for " $\mathrm{i}$ " firm when firms are ranged according to this variable.

$X$ : shows the total value of " $x$ " variable for all firms in a market.

According to CR 4 concentration ratio, market structure is classified as follows (Hamurcu and Durukan, 2009: 77-78):

- 0-30 range: Concentration is low (there is competition),

- 31-50 range: Concentration is medium (reduced competition, almost oligopoly),

- 51-70 range: Concentration is high (competition is redeced and oligopoly market is formed),

- 71-100 range: Concentration is very high (monopoly market is formed).

\section{Literature Review}

There are many studies related to market concentration in the literature. In these studies, market concentration of various industries were analyzed by using Herfindahl-Hirschman Index (HHI) and M- Firm Concentration Ratio to evaluate concentration degree in the markets and market structures.

Polat (2007) determined Turkish cement market structure by using data of cement firms' revenues, costs and output. According to M-firm concentration analyses, market strucure verged between monopolistic competition and oligopoly market. In terms of HerfindahlHirschman Index, more competitive structure was found.

Kaynak and Ari (2011) investigated the concentration level of Turkish automotive industry. According to $C R_{4}$, native trap market had high concentration level. In terms of $C R_{8}$, imported trap market had high level of concentration. In the same study, according to Herfindahl-Hirschman Index, native trap market showed monopolistic competition characteristics. On the other hand, imported trap market had low level of concentration. 
Haan and Poghosyan examined whether bank earnings volatility depended on bank size and the degree of concentration in the banking sector using quarterly data for non-investment banks in the United States for the period 2004Q1-2009Q4. They found that bank earnings volatility decreased with market concentration. They also found that larger banks located in concentrated markets experienced higher volatility during the recent financial crisis (Haan and Poghosyan, 2012).

Pehlivanoglu and Tekce (2013) examined electric energy market between the years 1993 and 2011 by analysing net sales profit of firms. Analyses results show that according to

【CR』_4, market has high concentration. According to Herfindahl - Hirschman Index, market has very high concentration.

Pulaj and Kume (2013) applied concentration ratio (CR4) method, HHI and Gini Coefficient to analyse the absolute concentration ratio and relative concentration ratio for construction industry market in Albania with 2003 to 2012 statistical data. The results revealed that the construction industry was a low concentrated industry because the industrial concentration ratios were below the threshold levels.

Ha and Seo compared cargo volumes and fleet capacity of top 4 transporters in Korean Ship Industry and their international counterparts between the years 1992 and 2004. Their findings showed that the concentration ratio was well below that of the global counterpart. Morover, the changes of CR4 between 1992 and 2004 indicated the Korean shipping market became more competitive and less concentrated. (Ha and Seo, 2013).

Nurwati (2014) investigated the relationship of market structure and performance for Indonesian Islamic Banks between the years 1999 and 2011. He found that there was a significant relation between market concentration and banks' equity conversion.

Trish and Herring (2015) examined the relationship between employer-sponsored fullyinsured health insurance premiums and the level of concentration in local insurer and hospital markets using the nationally-representative 2006-2011 KFF/HRET Employer Health Benefits Survey in the USA. They found that premiums were higher for plans sold in markets with higher levels of concentration relevant to insurer transactions with employers, lower for plans in markets with higher levels of insurer concentration relevant to insurer bargaining with hospitals, and higher for plans in markets with higher levels of hospital market concentration.

\section{An Emprical Study On Turkish Domestic Air Transport Market}

For this research, 2012-2015 data of domestic airlines (Turkish Airlines, Pegasus Airlines, Onur Air, AtlasGlobal Airlines, Borajet Airlines and Sun Express Airlines) which dominate Turkish domestic market were utilized. Within this scope, domestic passenger and domestic cargo data of 5 airports (Istanbul Ataturk Airport, Istanbul Sabiha Gokcen Airport, Ankara Esenboga Airport, Izmir Adnan Menderes Airport and Antalya Airport) which dominates airport markets were used. Herfindahl - Hirschman Index and Concentration Ratio values will be examined seperately.

\section{Airlines' Market Shares At Airports In Terms of Passenger and Cargo}

In this chapter, airlines' passenger numbers, cargo volume and market shares are analyzed in the biggest five airports in Turkey in terms of passenger and cargo taffic.

\section{Airlines' market shares at Istanbul Ataturk airport}

Table 2 and Table 3 presents data related to Istanbul Ataturk Airport. While Table 2 gives passenger traffic and market shares between 2012 and 2015, Table 3 presents cargo traffic and market shares. 
Table 2: Airlines' Passenger Numbers Market Shares at Istanbul Ataturk Airport

\begin{tabular}{lcccccccc}
\hline & \multicolumn{2}{c}{2012} & \multicolumn{2}{c}{$\mathbf{2 0 1 3}$} & \multicolumn{2}{c}{$\mathbf{2 0 1 4}$} & \multicolumn{2}{c}{$\mathbf{2 0 1 5}$} \\
\hline \multicolumn{1}{c}{ Airline } & Passenger & Market & Passenger & Market & Passenger & Market & Passenger & Market \\
& Numbers & Share \% & Numbers & Share \% & Numbers & Share \% & Numbers & Share \% \\
\hline Turkish Airlines & 10.322 .520 & 0,676 & 11.487 .011 & 0,667 & 12.939 .134 & 0,698 & 13.820 .377 & 0,7148 \\
Pegasus Airlines & 510.064 & 0,033 & 549.798 & 0,032 & 570.669 & 0,031 & 585.974 & 0,0303 \\
Onur Air & 2.638 .534 & 0,173 & 3.098 .786 & 0,180 & 3.022 .855 & 0,163 & 3.087 .338 & 0,1596 \\
Atlas Global & 1.796 .955 & 0,118 & 2.081 .639 & 0,121 & 2.009 .422 & 0,108 & 1.839 .894 & 0,0951 \\
Others & 2907 & 0,000 & 1438 & 0,000 & 215 & 0,000 & 290 & $\sim 0,010$ \\
Total & 15.270 .980 & 1,000 & 17.218 .672 & 1,000 & 18.542 .295 & 1,000 & 19.333 .873 & 1,000 \\
\hline
\end{tabular}

Table 2 presents passenger traffic data between 2012 and 2015 at Istanbul Ataturk Airport. According to the table, Turkish Airlines' market shares increased year by year. While its market share was at $67,6 \%$ in 2012 it increased to $71,48 \%$ in 2015 . Other airlines' market shares decreased significantly.

Table 3: Airlines' Cargo Market Shares at Istanbul Ataturk Airport

\begin{tabular}{|c|c|c|c|c|c|c|c|c|}
\hline \multirow[b]{2}{*}{ Airline } & \multicolumn{2}{|c|}{2012} & \multicolumn{2}{|c|}{2013} & \multicolumn{2}{|c|}{2014} & \multicolumn{2}{|c|}{2015} \\
\hline & Cargo (ton) & $\begin{array}{c}\text { Market } \\
\text { Share \% }\end{array}$ & $\begin{array}{c}\text { Cargo } \\
\text { (ton) }\end{array}$ & $\begin{array}{c}\text { Market } \\
\text { Share \% }\end{array}$ & Cargo (ton) & $\begin{array}{c}\text { Market } \\
\text { Share \% }\end{array}$ & $\begin{array}{c}\text { Cargo } \\
\text { (ton) }\end{array}$ & $\begin{array}{c}\text { Market } \\
\text { Share \% }\end{array}$ \\
\hline Turkish Airlines & N/A & N/A & 45803 & 0,960 & 47.999 & 0,971 & 42.111 & 0,9139 \\
\hline Pegasus Airlines & N/A & N/A & 155 & 0,003 & 108 & 0,002 & 65 & 0,0014 \\
\hline Onur Air & N/A & N/A & 1063 & 0,022 & 605 & 0,012 & 172 & 0,0037 \\
\hline Atlas Global & N/A & N/A & 672 & 0,014 & 584 & 0,012 & 1.596 & 0,0346 \\
\hline Others & N/A & N/A & 1 & 0,000 & 136 & 0,003 & 2.132 & 0,0462 \\
\hline Total & N/A & N/A & 47694 & 1,000 & 49432 & 1,000 & 46.075 & 1,0000 \\
\hline
\end{tabular}

Table 3 gives market share and cargo volume carried by airlines at Istanbul Ataturk Airport. Because the year 2012 data was not available it was showed as N/A. According to the table, Turkish Airlines' market share was too high and did not drop below $90 \%$ over the years.

\section{Airlines' market shares at Istanbul Sabiha Gokcen airport}

The data related to Istanbul Sabiha Gokcen Airport is given on Table 4 and Table 5. While Table 4 presents passenger traffic and market share between 2012 and 2015, Table 5 gives cargo traffic and market share.

Table 4: Airlines' Passenger Numbers data at Istanbul Sabiha Gokcen Airport

\begin{tabular}{lllllllllc}
\hline & \multicolumn{2}{c}{2012} & \multicolumn{2}{c}{2013} & \multicolumn{2}{c}{2014} & \multicolumn{2}{c}{2015} \\
\hline \multicolumn{1}{c}{ Airline } & Passenger & Market & Passenger & Market & Passenger & Market & Passenger & Market \\
& Numbers & Share \% & Numbers & Share \% & Numbers & Share \% & Numbers & Share \% \\
\hline Turkish Airlines & 1.635 .485 & 0,168 & 3.110 .356 & 0,261 & 4.410 .692 & 0,295 & 6.343 .622 & 0,3424 \\
Pegasus Airlines & 6.388 .787 & 0,655 & 7.944 .716 & 0,666 & 9.611 .593 & 0,643 & 11.200 .269 & 0,6045 \\
Onur Air & 0 & 0 & 0 & 0 & 0 & 0 & 253 & $\sim 0,0050$ \\
Atlas Global & 82.518 & 0,008 & 269.508 & 0,023 & 303.738 & 0,020 & 116.261 & 0,0062 \\
Sun Express & 1.585 .396 & 0,162 & 544837 & 0,045 & 447.450 & 0,030 & 443.534 & 0,0239 \\
Borajet & 62.317 & 0,006 & 57511 & 0,004 & 181.270 & 0,012 & 420.510 & 0,0226 \\
\hline
\end{tabular}




\begin{tabular}{lllllllll}
\hline \hline & & & & & & & \\
Others & 4.350 & 0,000 & 1.143 & 0,001 & 828 & 0,000 & 1200 & $\sim 0,0050$ \\
Total & 9758853 & 1,000 & 11.928 .074 & 1,000 & 14.955 .571 & 1,000 & 18.525 .649 & 1,0000 \\
\hline
\end{tabular}

Table 4 shows passenger traffic data at Istanbul Sabiha Gokcen Airport between 2012 and 2015. Accordingly, Pegasus Airlines' market share in 2012 was at $65 \%$ and decreased to $60 \%$ in 2015. In the same period, Turkish Airlines' market share doubled.

Table 5: Airlines' Cargo Volumes data at Istanbul Sabiha Gokcen Airport

\begin{tabular}{|c|c|c|c|c|c|c|c|c|}
\hline & \multicolumn{2}{|c|}{2012} & \multicolumn{2}{|c|}{2013} & \multicolumn{2}{|c|}{2014} & \multicolumn{2}{|r|}{2015} \\
\hline Airline & Cargo (ton) & $\begin{array}{c}\text { Market } \\
\text { Share \% }\end{array}$ & $\begin{array}{c}\text { Cargo } \\
\text { (ton) }\end{array}$ & $\begin{array}{c}\text { Market } \\
\text { Share \% }\end{array}$ & Cargo (ton) & $\begin{array}{c}\text { Market } \\
\text { Share \% }\end{array}$ & $\begin{array}{c}\text { Cargo } \\
\text { (ton) }\end{array}$ & $\begin{array}{c}\text { Market } \\
\text { Share \% }\end{array}$ \\
\hline Turkish Airlines & N/A & N/A & 674 & 0,190 & 1583 & 0,338 & 2.255 & 0,3659 \\
\hline Pegasus Airlines & N/A & N/A & 2833 & 0,798 & 2976 & 0,635 & 3.553 & 0,5765 \\
\hline Onur Air & N/A & N/A & 0 & 0,000 & 0 & 0 & 0 & 0 \\
\hline Atlas Global & N/A & N/A & 0,62 & 0,000 & 0 & 0 & 1 & 0,0000 \\
\hline Others & N/A & N/A & 41,38 & 0,012 & 127 & 0,027 & 352 & 0,0571 \\
\hline Total & N/A & N/A & 3549 & 1,000 & 4686 & 1,000 & 6.162 & 1,0000 \\
\hline
\end{tabular}

Table 5 presents market share and cargo volume carried by airlines at Istanbul Sabiha Gokcen Airport. Because the data related to 2012 was not available it was shown as N/A. According to the table, Pegasus Airlines' market share decreased significantly over the years. Accordingly, the $80 \%$ market share in 2012 decreased to 58\%. As for Turkish Airlines, its market share increased from $19 \%$ in 2012 to $36 \%$ in 2015.

\section{Airlines' market shares at Ankara Esenboga airport}

Table 6 and Table 7 presents the data related to Ankara Esenboga Airport. While Table 6 gives passenger traffic and market share between the years 2012 and 2015, Table 7 presents market share and cargo traffic.

Table 6: Airlines' data at Ankara Esenboga Airport

\begin{tabular}{|c|c|c|c|c|c|c|c|c|}
\hline \multirow[b]{3}{*}{ Airline } & \multicolumn{2}{|c|}{2012} & \multicolumn{2}{|c|}{2013} & \multicolumn{2}{|c|}{2014} & \multicolumn{2}{|c|}{2015} \\
\hline & & & & & Passenge & & & \\
\hline & $\begin{array}{c}\text { Passenger } \\
\text { Numbers }\end{array}$ & $\begin{array}{c}\text { Market } \\
\text { Share \% }\end{array}$ & $\begin{array}{c}\text { Passenger } \\
\text { Numbers }\end{array}$ & $\begin{array}{c}\text { Market } \\
\text { Share \% }\end{array}$ & $\begin{array}{c}\mathbf{r} \\
\text { Number } \\
\mathbf{s}\end{array}$ & $\begin{array}{c}\text { Market } \\
\text { Share \% }\end{array}$ & $\begin{array}{l}\text { Passenger } \\
\text { Numbers }\end{array}$ & $\begin{array}{r}\text { Market } \\
\text { Share \% }\end{array}$ \\
\hline Turkish Airlines & 6315925 & 0,822 & 7.963 .364 & 0,850 & 8141627 & 0,849 & 8.982 .389 & 0,8504 \\
\hline Pegasus Airlines & 1103765 & 0,144 & 1.271 .261 & 0,136 & 1350452 & 0,141 & 1.487 .220 & 0,1408 \\
\hline Onur Air & 0 & 0 & 0 & 0,000 & 7314 & 0,001 & N/A & N/A \\
\hline Atlas Global & 1112 & 0,000 & 369 & 0,000 & 0 & 0 & 1.654 & 0,0000 \\
\hline Borajet & 255909 & 0,033 & 131.547 & 0,014 & 88737 & 0,009 & 89.674 & 0,0084 \\
\hline Others & 2660 & 0,000 & 3.660 & 0,000 & 3220 & 0,000 & 1.346 & 0,0000 \\
\hline Total & 7679371 & 1,000 & 9.369 .832 & 1,000 & 9591350 & 1,000 & 10.562 .282 & 1,0000 \\
\hline
\end{tabular}

Table 6 shows passenger traffic data between the years 2012 and 2015 at Ankara Esenboga Airport. According to the table, Turkish Airlines' market share was significantly high. Its market share varied between $81 \%$ and $85 \%$. Other airlines' market share did not change significantly. Therefore, it might be said that Turkish Airlines dominate this market. 
Table 7: Airlines' data at Ankara Esenboga Airport

\begin{tabular}{|c|c|c|c|c|c|c|c|c|}
\hline \multirow[b]{2}{*}{ Airline } & \multicolumn{2}{|c|}{2012} & \multicolumn{2}{|c|}{2013} & \multicolumn{2}{|c|}{2014} & \multicolumn{2}{|r|}{2015} \\
\hline & Cargo (ton) & $\begin{array}{c}\text { Market } \\
\text { Share \% }\end{array}$ & $\begin{array}{c}\text { Cargo } \\
\text { (ton) }\end{array}$ & $\begin{array}{c}\text { Market } \\
\text { Share \% }\end{array}$ & Cargo (ton) & $\begin{array}{c}\text { Market } \\
\text { Share \% }\end{array}$ & $\begin{array}{c}\text { Cargo } \\
\text { (ton) }\end{array}$ & $\begin{array}{c}\text { Market } \\
\text { Share \% }\end{array}$ \\
\hline Turkish Airlines & N/A & N/A & 13005 & 0,988 & 13613 & 0,988 & 11.940 & 0,981 \\
\hline Pegasus Airlines & N/A & N/A & 159 & 0,012 & 165 & 0,012 & 226 & 0,019 \\
\hline Onur Air & N/A & N/A & 0 & 0,000 & 0 & 0 & 0 & 0 \\
\hline Atlas Global & N/A & N/A & 0 & 0,000 & 0 & 0 & 0 & 0 \\
\hline Others & N/A & N/A & 0 & 0,000 & 0 & 0 & 1 & 0,000 \\
\hline Total & N/A & N/A & 13164 & 1,000 & 13778 & 1,000 & 12.167 & 1,000 \\
\hline
\end{tabular}

Table 7 presents market share and cargo volume carried by airlines at Ankara Esenboga Airport. According to the table, Turkish Airlines has a monopoly over the market.

\section{Airlines' market shares at Izmir Adnan Menderes airport}

Table 8 and Table 9 presents the data related to Izmir Adnan Menderes Airport. While Table 8 gives passenger traffic and market share between the years 2012 and 2015, Table 9 shows Cargo traffic and market share in the same period.

Table 8: Airlines' data at Izmir Adnan Menderes Airport

\begin{tabular}{|c|c|c|c|c|c|c|c|c|}
\hline \multirow[b]{2}{*}{ Airline } & \multicolumn{2}{|c|}{2012} & \multicolumn{2}{|c|}{2013} & \multicolumn{2}{|c|}{2014} & \multicolumn{2}{|c|}{2015} \\
\hline & $\begin{array}{l}\text { Passenger } \\
\text { Numbers }\end{array}$ & $\begin{array}{c}\text { Market } \\
\text { Share \% }\end{array}$ & $\begin{array}{l}\text { Passenger } \\
\text { Numbers }\end{array}$ & $\begin{array}{c}\text { Market } \\
\text { Share \% }\end{array}$ & $\begin{array}{l}\text { Passenger } \\
\text { Numbers }\end{array}$ & $\begin{array}{c}\text { Market } \\
\text { Share \% }\end{array}$ & $\begin{array}{l}\text { Passenger } \\
\text { Numbers }\end{array}$ & $\begin{array}{c}\text { Market } \\
\text { Share \% }\end{array}$ \\
\hline Turkish Airlines & 2059069 & 0,296 & 2.596 .599 & 0,335 & 2840528 & 0,339 & 3.295 .949 & 0,3452 \\
\hline Pegasus Airlines & 2296976 & 0,331 & 2.760 .081 & 0,356 & 2930492 & 0,349 & 3.333 .870 & 0,3492 \\
\hline Onur Air & 445071 & 0,064 & 479.905 & 0,062 & 470195 & 0,056 & 559.740 & 0,0586 \\
\hline Atlas Global & 723970 & 0,104 & 552.882 & 0,071 & 563732 & 0,067 & 527.830 & 0,0552 \\
\hline Sun Express & 1416877 & 0,204 & 1.364 .516 & 0,176 & 1565066 & 0,187 & 1.789 .375 & 0,1874 \\
\hline Others & 3081 & 0,000 & 376 & 0,000 & 20412 & 0,002 & 38.679 & 0,0040 \\
\hline Total & 6945044 & 1,000 & 7.753 .983 & 1,000 & 8390425 & 1,000 & 9.545 .443 & 1,0000 \\
\hline
\end{tabular}

Table 8 presents passenger traffic data between 2012 and 2015 at Izmir Adnan Menderes Airport. According to the table, in terms of passenger market, Turkish Airlines and Pegasus Airlines had almost the same market shares. Moreover, Sun Express' market share varied between $17 \%$ and $20 \%$. These three airlines' total market share were at approximately $85 \%$.

Table 9: Airlines' data at Izmir Adnan Menderes Airport

\begin{tabular}{|c|c|c|c|c|c|c|c|c|}
\hline \multirow[b]{2}{*}{ Airline } & \multicolumn{2}{|c|}{2012} & \multicolumn{2}{|c|}{2013} & \multicolumn{2}{|c|}{2014} & \multicolumn{2}{|c|}{2015} \\
\hline & Cargo (ton) & $\begin{array}{c}\text { Market } \\
\text { Share \% }\end{array}$ & $\begin{array}{c}\text { Cargo } \\
\text { (ton) }\end{array}$ & $\begin{array}{c}\text { Market } \\
\text { Share \% }\end{array}$ & Cargo (ton) & $\begin{array}{c}\text { Market } \\
\text { Share \% }\end{array}$ & $\begin{array}{c}\text { Cargo } \\
\text { (ton) }\end{array}$ & $\begin{array}{c}\text { Market } \\
\text { Share \% }\end{array}$ \\
\hline Turkish Airlines & N/A & N/A & 17493 & 0,885 & 19204 & 0,896 & 18.314 & 0,8374 \\
\hline Pegasus Airlines & N/A & N/A & 1623 & 0,082 & 1700 & 0,079 & 2.213 & 0,1011 \\
\hline Onur Air & N/A & N/A & 35 & 0,002 & 1 & 0,000 & 0 & 0 \\
\hline Atlas Global & N/A & N/A & 541 & 0,027 & 411 & 0,019 & 1.249 & 0,0571 \\
\hline Others & N/A & N/A & 77 & 0,004 & 113 & 0,005 & 93 & 0,000 \\
\hline
\end{tabular}


Table 9 presents market shares and cargo volume carried by airlines at Izmir Adnan Menderes Airport. According to the table, Turkish Airlines dominates the market. Its market share was $88 \%$ in 2013 and decreased to $83.7 \%$ in 2015 .

\section{Airlines' market shares at Antalya airport}

Table 10 and Table 11 give data related to Antalya Airport. While Table 10 gives passenger traffic and market shares between 2012 and 2015; Table 11 presents cargo traffic and market shares.

Table 10: Airlines' data at Antalya Airport

\begin{tabular}{lllllllllc}
\hline & \multicolumn{2}{c}{2012} & \multicolumn{2}{c}{$\mathbf{2 0 1 3}$} & \multicolumn{2}{c}{2014} & & 2015 \\
\hline \multicolumn{1}{c}{ Airline } & Passenger & Market & Passenger & Market & Passenger & Market & Passenger & Market \\
& Numbers & Share \% & Numbers & Share \% & Numbers & Share \% & Numbers & Share \% \\
\hline Turkish Airlines & 1771477 & 0,359 & 2083217 & 0,377 & 2204715 & 0,354 & 2.632 .133 & 0,3811 \\
Pegasus Airlines & 972639 & 0,197 & 1323549 & 0,239 & 1575766 & 0,253 & 1.792 .702 & 0,2595 \\
Onur Air & 581899 & 0,118 & 632028 & 0,117 & 557090 & 0,089 & 576.397 & 0,0834 \\
Atlas Global & 675547 & 0,137 & 648147 & 0,150 & 900015 & 0,144 & 661.663 & 0,0958 \\
Sun Express & 870870 & 0,176 & 831517 & 0,114 & 925505 & 0,148 & 1.162 .354 & 0,1683 \\
Others & 68571 & 0,014 & 8027 & 0,001 & 67794 & 0,010 & 82015 & 0,0118 \\
Total & 4941003 & 1,000 & 5526485 & 1,000 & 6230885 & 1,000 & 6.906 .364 & 1,000 \\
\hline
\end{tabular}

Tablo 10 gives passenger traffic data between 2012 and 2015 at Antalya Airport. According to the table, in terms of passenger market, Turkish Airlines has the highest market share. Turkish Airlines' market share varies between $35 \%$ and $38 \%$. Pegasus Airlines increased its $19.7 \%$ market share in 2012 to approximately $26 \%$ in 2015 . Other airlines' market shares did not change significantly.

Table 11: Airlines' data at Antalya Airport

\begin{tabular}{|c|c|c|c|c|c|c|c|c|}
\hline \multirow[b]{2}{*}{ Airline } & \multicolumn{2}{|c|}{2012} & \multicolumn{2}{|c|}{2013} & \multicolumn{2}{|c|}{2014} & \multicolumn{2}{|r|}{2015} \\
\hline & $\begin{array}{c}\text { Cargo } \\
\text { (ton) }\end{array}$ & $\begin{array}{c}\text { Market } \\
\text { Share \% }\end{array}$ & $\begin{array}{c}\text { Cargo } \\
\text { (ton) }\end{array}$ & $\begin{array}{c}\text { Market } \\
\text { Share \% }\end{array}$ & Cargo (ton) & $\begin{array}{c}\text { Market } \\
\text { Share \% }\end{array}$ & $\begin{array}{c}\text { Cargo } \\
\text { (ton) }\end{array}$ & $\begin{array}{c}\text { Market } \\
\text { Share \% }\end{array}$ \\
\hline Turkish Airlines & N/A & N/A & 17493 & 0,885 & 5.314 & 0,873 & 4706 & 0,8520 \\
\hline Pegasus Airlines & N/A & N/A & 1623 & 0,082 & 465 & 0,076 & 403 & 0,0729 \\
\hline Onur Air & N/A & N/A & 35 & 0,002 & 64 & 0,011 & 65 & 0,0117 \\
\hline Atlas Global & N/A & N/A & 541 & 0,027 & 147 & 0,024 & 269 & 0,0487 \\
\hline Others & N/A & N/A & 77 & 0,004 & 99 & 0,016 & 80 & 0,0144 \\
\hline Total & N/A & N/A & 19769 & 1,000 & 6089 & 1,000 & 5.523 & 1,000 \\
\hline
\end{tabular}

Table 11 indicates market share and cargo volume carried by airlines at Antalya Airport. According to the table, Turkish Airlines dominates the market. The relevant airline's market share varies between $85 \%$ and $88 \%$.

\section{Concentration Ratio for Turkish Domestic Passenger and Cargo Markets}

\section{CR4 domestic passenger and cargo market concentration ratios}

Table 12: Domestic Passenger and Cargo Market Concentration Ratios according to $C R_{4}$ 


\begin{tabular}{|c|c|c|c|c|c|c|c|}
\hline \multirow{2}{*}{ Airport } & & \multicolumn{4}{|l|}{ Value } & \multirow{2}{*}{ Value Range } & \multirow{2}{*}{ CR Market Definition } \\
\hline & & 2012 & 2013 & 2014 & 2015 & & \\
\hline \multirow{2}{*}{ Istanbul Ataturk A. } & Passenger & $\sim 1,00$ & 0,999 & $\sim 1,00$ & 0,998 & $C R_{4} \geq 70$ & Almost Monopol, High Intensive Market \\
\hline & Cargo & NA & 0,999 & $\sim 1,00$ & 0,965 & $C R_{4} \geq 70$ & Almost Monopol, High Intensive Market \\
\hline \multirow{2}{*}{ Ist. Sabiha Gokcen A. } & Passenger & 0,993 & 0,949 & 0,988 & 0,991 & $C R_{4} \geq 70$ & Almost Monopol, High Intensive Market \\
\hline & Cargo & NA & 0,988 & $\sim 1,00$ & 0,999 & $C R_{4} \geq 70$ & Almost Monopol, High Intensive Market \\
\hline \multirow{2}{*}{ Ankara Esenboga A. } & Passenger & 0,999 & 0,986 & $\sim 1,00$ & 0,999 & $C R_{4} \geq 70$ & Almost Monopol, High Intensive Market \\
\hline & Cargo & NA & $\sim 1,00$ & $\sim 1,00$ & 0,999 & $C R_{4} \geq 70$ & Almost Monopol, High Intensive Market \\
\hline \multirow{2}{*}{ Adnan Menderes A. } & Passenger & 0,935 & 0,824 & 0,931 & 0,940 & $C R_{4} \geq 70$ & Almost Monopol, High Intensive Market \\
\hline & Cargo & NA & 0,996 & $\sim 1,00$ & 0,995 & $C R_{4} \geq 70$ & Almost Monopol, High Intensive Market \\
\hline \multirow{2}{*}{ Antalya A. } & Passenger & 0,869 & 0,884 & 0,900 & 0,904 & $C R_{4} \geq 70$ & Almost Monopol, High Intensive Market \\
\hline & Cargo & NA & 0,999 & 0,989 & 0,988 & $C R_{4} \geq 70$ & Almost Monopol, High Intensive Market \\
\hline
\end{tabular}

Table 12 indicates domestic passenger and cargo market concentration ratios according to CR4 between 2012 and 2015. If $C R_{4}$ concentration ratio is between 0 and 30, that means there is low level of concentration. This range is the proof of competition. The range of 31-50 indicates medium concentration level thus, competition is reducing and there is a situation which is near oligopoly. The range of 51-70 shows that there is high level of concentration thus, competition decreases extremly in other words, there is oligopoly market structure. Lastly, the range of 71-100 indicates there is very high level of concentration. This market structure shows monopolistic characteristics (Durukan and Hamurcu, 2009: 77-78). Data from table 12 reveals that all airports are near monopoly. Although $C R_{4}$ values differs across different airports, all airports' values are higher than critical value of 70 . In other words, all airports have a high degree of concentration.

Although there are many studies which evaluate the airport situation of being natural monopoly (Gillen, 2011; Starkie, 2002; Gerber, 2002; Niemeier, 2002) this study aims to exhibit differences in concentration degrees across airports in Turkey. When viewed from this aspect, in terms of passenger numbers, Istanbul Ataturk Airport is close to monopoly. It is followed by Ankara Esenboga Airport. Izmir Adnan Menderes Airport is the most distant from being a monopoly. Although airport market concentration ratios varied by years, no variations from monopol structure is visible.

Examining cargo market concentration ratios reveals that $C R_{4}$ values are near 1 . This indicates that cargo market is closer to monopoly. Cargo market concentration rate was close to 1 by years and monopol structure gained importance.

\section{Domestic Passenger and Cargo Market Concentration Ratios According To HHI}

Table 13: Domestic Passenger and Cargo Market Concentration Ratios in terms of HHI

\begin{tabular}{ccccccccc}
\hline & & \multicolumn{3}{c}{ HHI Value } & & \\
Airport & & & & & & HHI Value Range & HHI Market Definition \\
& & $\mathbf{2 0 1 2}$ & $\mathbf{2 0 1 3}$ & $\mathbf{2 0 1 4}$ & $\mathbf{2 0 1 5}$ & & \\
\hline $\begin{array}{r}\text { Istanbul } \\
\text { Ataturk A. }\end{array}$ & Passenger & 5066 & 4929 & 5086 & 5464 & $4000<H H I<10000$ & Almost Monopol, High Intensive Market \\
\cline { 5 - 7 } & Cargo & NA & 9222 & 9411 & 8385 & $4000<H H I<10000$ & Almost Monopol, High Intensive Market \\
\hline
\end{tabular}




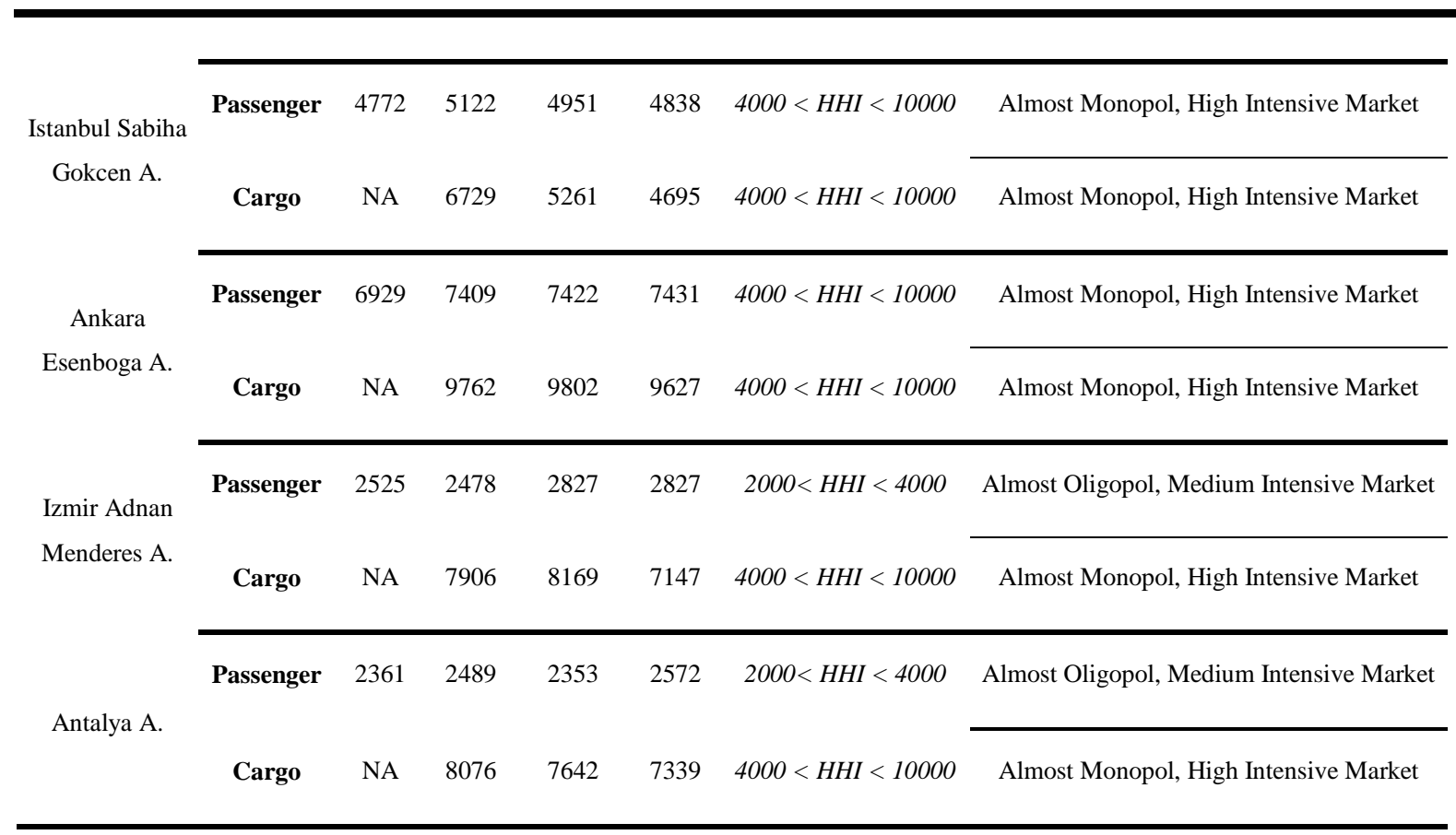

Table 13 shows Turkish domestic and cargo markets HHI values, value ranges and market definitions. Maximum value of HHI can be 10.000. If there are many firms in a market and their market shares are insignificant, HHI value is near zero. In other words, HHI value decreases when market is close to pure competition. Moreover, the value of HHI 0-2000 indicates low concentration markets, the value of HHI 2000-4000 shows medium concentration markets and the value of HHI 4000-10000 indicates high concentration markets (Su, 2003: 2021).

According to HHI, domestic passenger market concentration indicates that almost all airports have monopoly market structures. Moreover, cargo markets in all airports have monopoly market structures. Izmir Adnan Menderes and Antalya airports in terms of passenger market are more competitive and have oligopoly market structures. By contrast with this, other markets do not show competitive structures and only a few companies have all the market. Turkish domestic passenger and cargo markets HHI values share smilarities with $C R_{4}$ values. In other words, both tests' results are close to each other and coherent.

\section{Conclusion and Evaluation}

To determine aviation market structure and examine this quantitively are crucial for both market players and decision makers. By this means, it might be possible to develop qualified politics and increase competition for ever-growing and ever-changing aviation industry.

In this study, Turkish domestic passenger and cargo markets were examined by years. In this regard, top five airports in terms of passenger and cargo transported were examined to determine which market structure they had. M-Firm Concentration Ratio $\left(C R_{M}\right)$ and Herfindahl-Hirschman Index (HHI) were used to reveal market structure and examine market concentration. Moreover, in this study, airlines' market shares at airports were mentioned.

M-Firm Concentration Ratio $\left(C R_{M}\right)$ analyses showed that all airports in terms of passenger and cargo data had the highest level of concentration ratios. This situation indicated that market is far away from competition.

In terms of $C R_{4}$ market concentration ratio, the nearest to monopoly in respect to passenger numbers is Istanbul Ataturk Airport. It is followed by Ankara Esenboga Airport with its 0,986 concentration ratio. When cargo market concentration ratios are examined, $C R_{4}$ value range is very high (almost 1). This indicates that cargo market shows monopolistic 
characteristics. The highest $C R_{4}$ value range for cargo markets is Ankara Esenboga Airport. Concentration ratio here is very close to 1 .

In terms of Turkish domestic passenger and cargo market HHI values, value ranges and market definitions, Ankara Esenboga Airport has the highest HHI value in domestic market. This situation shows that this market is far away from competition. On the other hand, Izmir Adnan Menderes Airport and Antalya Airport have the lowest market concentration ratios in domestic passenger market. Their HHI values are near 2500. This indicates that there is relatively competition in these airports. These airports can be evaluated as low concentration airports. Moreover, domestic cargo market HHI reveals that it has higher concentration market structure than passenger markets have. In other words, domestic cargo markets are more concentrated than passenger markets. The nearest to monopoly market structure is Ankara Esenboga Airport. It is followed by Istanbul Ataturk Airport, Izmir Adnan Menderes Airport, Antalya Airport and Istanbul Sabiha Gokcen Airport respectively.

The analysis of airports' market structure in Turkey reveals that they are distant from competition and close to monopoly. This situation inhibits development of aviation and people's accession to the aviation. Monopoly structure leads to high prices, poor quality and unprecedented to passengers. To make airports more competitive in Turkey, privileges to public airline should be avoided, the market should be reorganized and some subventions should be carried into effect. Thanks to these precautions, air transportation in Turkey will develop and society benefit and contribution will reach to significant levels.

The results of this research contribute to both determining market structure and guiding decision makers. In addition to that, being the first research on airport market concentration in Turkey increases original value of this study. In this research, only 4 years period was considered in determining market concentration, however, it is recommended that further research might consider more years and examine changes living in aviation markets. This is extremly important for monitoring the development of market structure.

\section{References}

Aktan, C. C., Y.Vural, İ. (2004). Yeni Ekonomi ve Yeni Rekabet. Ankara: Türkiye İşveren Sendikaları Konfederasyonu.

ATAG. (2014). Aviation Benefits Beyond Borders. Geneva: Air Transport Action Group.

ATIG. (2015). ATIG Havayolu Sektör Raporu. İstanbul: ATIG Yatırım Menkul Değerler A.Ş. Baş, M.(2005), "Rekabeti Etkileyen Faktörlerden Pazar Yoğunlaşması Ve Ülkemizdeki Bazı Sektörlerin Yoğunlaşma Dereceleri”, Üçüncü Sektör Kooperatifçilik Dergisi, 148, Ankara, April-July 2005.

Batmaz, N., Özcan, A. (2008). Yeniliği Etkileyen Unsurlar ve Toplumsal Refah İlişkisi International Journal of Economic and Administrative Studies(1), pp.43-66.

Battal, Ü., Yılmaz, H., and Ateş, S. S. (2006). Türkiye'de İç Hatlarda Serbestleşme ve Geleceği, Conference Paper Presented on Kayseri VI. Havacılık Sempozyumu. Nevşehir.

DHMİ. (2015, Mayıs 10). DHMİ: İstatistikler. Available at: www.dhmi.gov.tr (accessed on 11.05.2015)

Durukan, T, Hamurcu Ç. (2009) "Mobil İletişimde Pazar Yoğunlaşması: Türkiye ile Kazakistan, Kırgızistan Tacikistan, Türkmenistan ve Özbekistan Karşılaştırması." Karadeniz Araştırmaları 22.22: pp.75-86.

Gerede, E., \& Orhan, G. (2015). Bölüm 6: Türk Havayolu Taşımacılığındaki Ekonomik Düzenlemelerin Gelişim Süreci. In Section E. GEREDE, Havayolu Taşımacılığı ve Ekonomik Düzenlemeler Teori ve Türkiye Uygulaması, pp.164-208. Ankara: Sivil Havacılık Genel Müdürlüğü. 
Gillen, D. (2011), "The evolution of airport ownership and governance." Journal of Air Transport Management 17.1: pp.3-13.

Gerber, P (2002). "Success factors for the privatisation of airports - an airline perspective." Journal of Air Transport Management 8.1: pp.29-36.

Günlü, A. (2011). Çiğ Süt Pazarlanmasında Süt Sanayi İşletmelerinde Firma Yoğunlaşma Oranlarının Araştırılması: Burdur İli Örneği. Kafkas Universitesi Veteriner Fakultesi Dergisi, 17(1).

Grant, R. M. (2008). Contemporary Strategy Analysis Sixth Edition. Malden Mass. UK: Blackwell Pub.

Ha, Y. S., and Seo, J. S. (2013). An analysis of market concentration in the Korean liner shipping industry. The Asian Journal of Shipping and Logistics,29(2), 249-266.

IATA. (2011). The Impacts of September 112001 on Aviation. Available at: http://www.iata.org/pressroom/documents/impact-9-11-aviation.pdf (accessed on: 10.05.2015) Korul, V., Küçükonal, H. (2003). Türk Sivil Havacılık Sisteminin Yapısal Analizi. Ege Akademik Bakış, 3(1-2), pp.25-38.

Lipsey, R. G., Steiner, P. O. and Purvis, D. D. (1987). Economics: Eight Edition. New York: Harper \& Row.

McNulty, P. J. (1968). Economic Theory and Meaning of Competition. Quarterly Journal of Economics, 82(4), pp.639-656.

Niemeier, H. M. (2002), "Regulation of airports: the case of Hamburg airport - a view from the perspective of regional policy." Journal of Air Transport Management 8.1: pp.37-48.

Nurwati, E., Achsani, N. A., Hafidhuddin, D. and Nuryartono, N. (2014). Market Structure and Bank Performance: Empirical Evidence of Islamic Banking in Indonesia. Asian Social Science, 10(10), pp.105.

Oktal, H., Gerede, E. (2002). Türk Sivil Havacılık Otoritesinin Yeniden Yapılandırılması. Amme İdaresi Dergisi, 35(4), pp.103-120.

Özkan, R. B. (2007). Rekabet Stratejileri ve Örnek Bir Sektör Analizi Yüksek Lisans Tezi. İstanbul: Marmara Üniversitesi Sosyal Bilimler Enstitüsü İktisat A.B.D.

Pehlivanoğlu, F., Tekçe, E. (2013). Türkiye Elektrik Enerjisi Piyasasında HerfindahlHirschman ve CRm Endeksleri ile Yoğunlaşma Analizi. Abant İzzet Baysal Üniversitesi Sosyal Bilimler Enstitüsü Dergisi.

Polat, Ç. (2007), "Yogunlaşma ve Piyasa Yapısı İlişkisi Çerçevesinde Türk Çimento Sektörünün Yapısal Analizi”, Anadolu Üniversitesi Sosyal Bilimler Enstitüsü Dergisi, 7(2), pp.97-116,

Silva, C. E. (2007). The Theory of Imperfect Competition: A review of the post-keynesian contribition. Porto Alegre, 18(2), pp.38-53.

SHGM. (2015). SHGM Faaliyet Raporu 2015. Ankara: Sivil Havacılık Genel Müdürlüğü.

Starkie D. (2002), "Airport regulation and competition." Journal of Air Transport Management 8.1: pp.63-72.

Su, K.T. (2003), Rekabet Hukukunda Teşebbüslerin Hakim Durumunun Belirlenmesinde Pazar Gücünün Ölçülmesi. Rekabet Kurumu,

Süslü, B., Baydur, C. M. (1999). Bankac1lık Sektöründe Yoğunlaşma. Ankara Üniversitesi SBF Dergisi, 54(3), pp. 151-163.

TBMM. (2001, April 11). Kanun Tasarısının Metni, available at: http://www2.tbmm.gov.tr/d21/1/1-0838.pdf (accessed on 10.05.2015).

TÜİK. (2014, March 31). Statistics, available at: http://www.tuik.gov.tr/PreHaberBultenleri.do?id=16191 (accessed on 12.05.2015)

UBAK. (2014). Havacilık ve Uzay Teknolojileri Faaliyet Raporu. Ankara: Ulaştırma Bakanlığ1, available at: http://ubak.gov.tr/images/faaliyet/a5ec26a31a72281.pdf, (accessed on 15.05.2015). 
Uysal, E., Özütürk, B. (2005) Türk Menkul Kıymet Yatırım Fonu Sektöründe Yoğunlaşma. Maliye Araştırma Merkezi Konferansları (p. 274) İstanbul: İstanbul Üniversitesi İktisat Fakültesi

Vickers, J. (1995). Concepts of Competition. Oxford Economic Papers, 5. 
APPENDIX A: Top 10 Airports İn Terms Of Commercial Airplane Traffic

\begin{tabular}{|c|c|c|c|c|c|c|c|c|c|c|c|c|}
\hline \multirow{3}{*}{ AIRPORTS } & \multicolumn{9}{|c|}{ COMMERCIAL AIR TRAFFIC } & \multirow{2}{*}{\multicolumn{3}{|c|}{ END OF DECEMBER 2015}} \\
\hline & \multicolumn{3}{|c|}{ END OF DECEMBER 2012} & \multicolumn{3}{|c|}{ END OF DECEMBER 2013} & \multicolumn{3}{|c|}{ END OF DECEMBER 2014} & & & \\
\hline & Domestic & International & Total & Domestic & International & Total & Domestic & International & Total & Domestic & International & Total \\
\hline Istanbul Ataturk & 114.767 & 231.293 & 346.060 & 126.566 & 259.432 & 385.998 & 132.965 & 286.932 & 419.897 & 132.873 & 314.071 & 446.944 \\
\hline Istanbul Sabiha Gökcen & 70.051 & 41.864 & 111.915 & 83.335 & 51.130 & 134.465 & 105.467 & 65.826 & 171.293 & 129.117 & 75.713 & 204.830 \\
\hline Antalya & 33.447 & 117.684 & 151.131 & 38.022 & 120.825 & 158.847 & 42.176 & 122.584 & 164.760 & 45.573 & 116.087 & 161.660 \\
\hline Ankara Esenboga & 61.594 & 13.266 & 74.860 & 72.026 & 13.051 & 85.077 & 70.468 & 11.640 & 82.108 & 75.836 & 12.134 & 87.970 \\
\hline Izmir Adnan Menderes & 49.339 & 17.078 & 66.417 & 52.599 & 16.617 & 69.216 & 55.325 & 17.372 & 72.697 & 60.415 & 19.156 & 79.571 \\
\hline Adana & 22.960 & 4.995 & 27.955 & 26.963 & 4.387 & 31.350 & 28.739 & 5.915 & 34.654 & 31.186 & 6.522 & 37.708 \\
\hline Mugla Milas-Bodrum & 7.003 & 15.863 & 22.866 & 12.718 & 11.215 & 23.933 & 15.103 & 11.205 & 26.308 & 16.374 & 9.910 & 26.284 \\
\hline Mugla Dalaman & 12.301 & 11.477 & 23.778 & 6.816 & 17.450 & 24.266 & 7.372 & 18.323 & 25.695 & 9.109 & 17.952 & 27.061 \\
\hline Trabzon & 16.852 & 531 & 17.383 & 17.141 & 910 & 18.051 & 17.569 & 1.136 & 18.705 & 22.126 & 911 & 23.037 \\
\hline Gaziantep & 9.088 & 1.784 & 10.872 & 12.033 & 1.164 & 13.197 & 13.490 & 1.304 & 14.794 & 14.452 & 1.282 & 15.374 \\
\hline TURKEY TOTAL & 483.441 & 463.456 & 946.897 & 554.166 & 505.225 & 1.059.391 & 606.063 & 553.774 & 1.159 .837 & 668.817 & 585.798 & 1.254 .615 \\
\hline
\end{tabular}


APPENDIX B: Top 10 Airports İn Terms Of Passenger Traffic

\begin{tabular}{|c|c|c|c|c|c|c|c|c|c|c|c|c|}
\hline \multirow{3}{*}{ Airports } & \multicolumn{9}{|c|}{ PASSENGER TRAFFIC (Inbound-Outbound) } & & & \\
\hline & \multicolumn{3}{|c|}{ END OF DECEMBER 2012} & \multicolumn{3}{|c|}{ END OF DECEMBER 2013} & \multicolumn{3}{|c|}{ END OF DECEMBER 2014} & \multicolumn{3}{|c|}{ END OF DECEMBER 2015} \\
\hline & Domestic & International & Total & Domestic & International & Total & Domestic & International & Total & Domestic & International & Total \\
\hline Istanbul Ataturk & 15.279 .655 & 29.812 .307 & 45.091 .962 & 17.218 .672 & 34.079 .118 & 51.297 .790 & 18.542 .295 & 38.152 .871 & 56.695 .166 & 19.333 .873 & 41.998 .251 & 61.332 .124 \\
\hline Antalya & 4.943 .308 & 20.152 .836 & 25.096 .144 & 5.526 .485 & 21.492 .138 & 27.018 .623 & 6.230 .885 & 22.072 .307 & 28.303 .192 & 6.906 .364 & 20.863 .040 & 27.769 .404 \\
\hline $\begin{array}{l}\text { Istanbul Sabiha } \\
\text { Gokcen }\end{array}$ & 8.704 .249 & 4.420 .421 & 13.124 .670 & 11.928 .074 & 6.593 .688 & 18.521 .762 & 14.955 .571 & 8.539 .075 & 23.494 .646 & 18.525 .649 & 9.583 .089 & 28.108 .738 \\
\hline Ankara Esenboga & 7.080 .072 & 1.405 .395 & 8.485 .467 & 9.369 .832 & 1.572 .228 & 10.942 .060 & 9.591 .350 & 1.444 .256 & 11.035 .606 & 10.562 .282 & 1.551 .157 & 12.113 .439 \\
\hline $\begin{array}{l}\text { Izmir Adnan } \\
\text { Menderes }\end{array}$ & 6.125 .076 & 2.398 .457 & 8.523 .533 & 7.753 .983 & 2.479 .157 & 10.233 .140 & 8.390 .425 & 2.580 .238 & 10.970 .663 & 9.545 .443 & 2.632 .657 & 12.178 .100 \\
\hline Adana & 2.651 .873 & 589.094 & 3.240 .967 & 3.754 .227 & 561.551 & 4.315 .778 & 4.057 .291 & 630.203 & 4.687 .494 & 4.582 .185 & 727.521 & 5.309 .706 \\
\hline Mugla Dalaman & 696.644 & 3.035 .730 & 3.372 .374 & 851.704 & 3.203 .926 & 4.055 .630 & 1.012 .396 & 3.297.084 & 4.309 .480 & 1.229 .318 & 3.152 .765 & 4.382 .083 \\
\hline $\begin{array}{l}\text { Mugla Milas- } \\
\text { Bodrum }\end{array}$ & 1.396 .493 & 1.991 .842 & 3.388 .335 & 1.738 .027 & 1.890 .293 & 3.628 .320 & 2.011 .444 & 1.835 .103 & 3.846 .547 & 2.309 .115 & 1.568 .758 & 3.877 .873 \\
\hline Trabzon & 2.190 .503 & 89.514 & 2.280 .017 & 2.528 .990 & 91.897 & 2.620 .887 & 2.668 .349 & 109.187 & 2.777 .536 & 3.249 .120 & 113.679 & 3.362 .799 \\
\hline Gaziantep & 1.170 .025 & 144.483 & 1.314 .508 & 1.662 .457 & 166.342 & 1.828 .799 & 1.889 .937 & 192.884 & 2.082 .821 & 2.136 .123 & 195.104 & 2.331 .227 \\
\hline $\begin{array}{l}\text { TURKEY } \\
\text { TOTAL }\end{array}$ & 58.258.324 & 59.362 .145 & 117.620 .469 & 76.148.526 & 73.281.895 & 149.430 .421 & 85.416.166 & 80.304.068 & 165.720 .234 & 97.041.210 & 84.033.321 & 181.074.531 \\
\hline
\end{tabular}


Appendix C: Top 10 airports in terms of cargo traffic

\begin{tabular}{|c|c|c|c|c|c|c|c|c|c|c|c|c|}
\hline \multicolumn{13}{|c|}{ CARGO TRAFFIC (Ton) } \\
\hline \multirow{2}{*}{ AIRPORTS } & \multicolumn{3}{|c|}{ END OF DECEMBER 2012} & \multicolumn{3}{|c|}{ END OF DECEMBER 2013} & \multicolumn{3}{|c|}{ END OF DECEMBER 2014} & \multicolumn{3}{|c|}{ END OF DECEMBER 2015} \\
\hline & Domestic & International & Total & Domestic & International & Total & Domestic & International & Total & Domestic & International & Total \\
\hline Istanbul Ataturk & N/A & N/A & N/A & 44.360 & 586.319 & 630.679 & 45.596 & 682.888 & 728.485 & 43,763 & 746,981 & 790,744 \\
\hline $\begin{array}{c}\text { Istanbul Sabiha } \\
\text { Gokcen }\end{array}$ & N/A & N/A & N/A & 3.545 & 29.340 & 32.885 & 4.618 & 34.828 & 39.447 & 6,153 & 44,716 & 50,868 \\
\hline Izmir Adnan Menderes & N/A & N/A & N/A & 19.152 & 2.087 & 21.239 & 20.702 & 2.341 & 23.043 & 21,478 & 3,161 & 24,640 \\
\hline Ankara Esenboga & N/A & N/A & N/A & 12.047 & 2.514 & 14.561 & 12.230 & 6.687 & 18.918 & 11,243 & 4,431 & 15,674 \\
\hline Trabzon & N/A & N/A & N/A & 2.290 & 8.627 & 10.918 & 2.190 & 7.677 & 9.867 & 1,854 & 51 & 1,904 \\
\hline Antalya & N/A & N/A & N/A & 5.041 & 1.598 & 6.639 & 5.590 & 2.278 & 7.867 & 5,311 & 2,472 & 7,783 \\
\hline Adana & N/A & N/A & N/A & 5.907 & 186 & 6.093 & 5.774 & 410 & 6.184 & 5,202 & 738 & 5,940 \\
\hline Gaziantep & N/A & N/A & N/A & 1.931 & 4 & 1.936 & 1.983 & 1 & 1.984 & 1,604 & 11 & 1,615 \\
\hline Diyarbakir & N/A & N/A & N/A & 1.097 & 0 & 1.097 & 1.044 & 0 & 1.044 & 719 & 0 & 719 \\
\hline Samsun Carsamba & N/A & N/A & N/A & 635 & 65 & 700 & 706 & 8 & 714 & 651 & 11 & 662 \\
\hline TURKEY TOTAL & N/A & N/A & N/A & 100.097 & 631.865 & 731.961 & 104.941 & 737.300 & 842.241 & 101,447 & 803,884 & 904,762 \\
\hline
\end{tabular}

